\title{
Persistence of Piscirickettsia salmonis and detection of serum antibodies to the bacterium in white seabass Atractoscion nobilis following experimental exposure
}

\author{
Kristen D. Arkush ${ }^{1,2, *}$, Holly L. Edes ${ }^{1}$, Anne M. McBride ${ }^{1}$, Mark A. Adkison ${ }^{3}$, \\ Ronald P. Hedrick ${ }^{2}$ \\ ${ }^{1}$ Bodega Marine Laboratory, PO Box 247, Bodega Bay, California 94923, USA \\ ${ }^{2}$ Department of Medicine and Epidemiology, School of Veterinary Medicine, University of California, One Shields Avenue, \\ Davis, California 95616, USA \\ ${ }^{3}$ California Department of Fish and Game, 2111 Nimbus Road, Rancho Cordova, California 95670, USA
}

\begin{abstract}
White seabass Atractoscion nobilis surviving experimental exposure to Piscirickettsia salmonis harbored the bacterium for periods up to at least $123 \mathrm{~d}$ post injection (dpi). Intraperitoneal injections of juvenile white seabass with $1.26 \times 10^{2} \mathrm{TCID}_{50}$ P. salmonis fish ${ }^{-1}$ resulted in a $29 \%$ cumulative mortality over a $27 \mathrm{~d}$ period. Both molecular and histologic methods provided evidence for persistence of the bacterium in fish sampled sequentially from the surviving population. Throughout the period of acute mortality, the bacterium was detected in all impression smears of liver tissue stained with Giemsa and was reisolated in cell cultures from all dead fish sampled. Polymerase chain reaction (PCR) assays detected P. salmonis-specific DNA in 13.3 to $50 \%$ of the fish sampled at time points between 28 and $123 \mathrm{dpi}$, while cell culture reisolation was largely ineffective in detecting the bacterium. An enzyme-linked immunosorbent assay (ELISA) detected serum anti-P. salmonis antibodies in 48 of 59 white seabass exposed to $P$. salmonis but not in fish which were not exposed to the bacterium. At the end of the 4 mo experiment, microscopic lesions consisting of single to multiple and coalescing granulomas were found in liver and kidney tissues of 9 of 10 fish examined from the exposure group, while no lesions were detected in the fish from the control group. Immunohistochemical staining with anti- $P$. salmonis polyclonal antibodies detected bacterial antigens in some but not all granulomas examined from the exposure group at 4 mo. This study demonstrates that $P$. salmonis may persist among white seabass following infection and thus provide a potential reservoir of infection contributing to transmission both within and between fish species in the marine environment.
\end{abstract}

KEY WORDS: Piscirickettsia salmonis $\cdot$ White seabass $\cdot$ Persistent infection $\cdot$ Carrier state

\section{INTRODUCTION}

Piscirickettsia salmonis, the obligate intracellular bacterium associated with piscirickettsiosis, was first observed among coho salmon Oncorhynchus kisutch reared in net pens off the coast of Chile in 1989 (Bravo \& Campos 1989). Since that initial report, P. salmonis has been found in farmed salmonid fish in Norway, Scotland, Ireland and both the Atlantic and Pacific coasts of Canada (Cvitanich et al. 1991, Brocklebank et al. 1992, Evelyn 1992, Fryer et al. 1992, Rodger \& Drinan 1993, Olsen et al. 1997, Cusak et al. 2002). Piscirickettsiosis is manifested principally as a systemic disease with the most severe inflammation and necrosis occurring in the liver, kidney, spleen and intestine (Fryer \& Hedrick 2003). An additional but less often encountered neurologic syndrome is associated with $P$. salmonis where most bacteria are found in the brain 
with lesser amounts in visceral organs (Comps et al. 1996, Grant et al. 1996, Skarmeta et al. 2000, McCarthy et al. 2005). P. salmonis and P. salmonis-like bacteria have been detected from a variety of marine and freshwater fish (Mauel \& Miller 2002). Two of these bacteria from marine fish recently have been confirmed to be $P$. salmonis by phylogenetic comparisons of the small and large subunit ribosomal (16S and 23S) DNA and the internal transcribed spacer (ITS) (Arkush et al. 2005, McCarthy et al. 2005). Arkush et al. (2005) demonstrated that P. salmonis causes a disease similar to piscirickettsiosis in white seabass Atractoscion nobilis. Experimental infections with the bacterium caused mortality similar to that of $P$. salmonis infections in salmon, with granulomatous lesions principally in the liver and to a lesser extent in the spleen, kidney, intestine and gills. McCarthy et al. (2005) also confirmed P. salmonis as a pathogen in European sea bass Dicentrarchus labrax. Interestingly, in their report, as in an earlier report of $P$. salmonis-like infection in European seabass (Comps et al. 1996), the most significant pathology was associated with the brain of infected fish.

Since the first description of Piscirickettsia salmonis from salmonid fish in Chile, the source of the bacterium has been a subject of interest. Infections in freshwater fish have been reported but are rare (Bravo \& Campos 1989, Cvitanich et al. 1991). However, since the bacterium has been confirmed in 2 marine species (Arkush et al. 2005, McCarthy et al. 2005), there is growing evidence that marine fish may serve as reservoirs of the bacterium. That isolates of $P$. salmonis recovered from marine fish like the white seabass can induce disease and mortality (80\%) in experimentally infected juvenile coho salmon has been demonstrated (Chen et al. 2000). More thorough virulence tests with the isolate from white seabass (WSB98) have shown it to be highly lethal to juvenile coho salmon, inducing a higher mortality (98\%) than equal doses of LF-89 (95\%), the reference strain of P. salmonis originally isolated from coho salmon (House et al. in press). Arkush et al. (2005) also showed that Chinook salmon Oncorhynchus tshawytscha and coho salmon cohabited with $P$. salmonis-infected white seabass can contract the bacterium. The shedding from resident marine fish, survival of the bacterium in seawater (Lannan \& Fryer 1994) and transmission between fish species may represent key pathways by which $P$. salmonis is maintained in the marine environment. In the present report, both molecular and histologic methods were used to examine the persistence of $P$. salmonis, while serologic testing was used to evaluate the humoral response by detecting serum anti$P$. salmonis among white seabass surviving experimental exposures to the bacterium.

\section{MATERIALS AND METHODS}

Fish. The juvenile white seabass Atractoscion nobilis used in this study originated from the Leon Raymond Hubbard Jr., Marine Fish Hatchery, a Hubbs-SeaWorld Research Institute facility supplied with seawater from a local lagoon in Carlsbad, California, USA. The fish were transported to the pathogen containment facility at the Bodega Marine Laboratory, Bodega Bay, California. The white seabass were held in fiberglass tanks supplied with flow-through seawater maintained at 15 to $16^{\circ} \mathrm{C}$, and were fed a commercial ration at $2 \%$ body wt $\mathrm{d}^{-1}$. At the beginning of the exposures, the fish were $165 \mathrm{~d}$ in age.

Growth of bacterium. The WSB-98 isolate of Piscirickettsia salmonis used in this study was originally isolated from liver tissue of moribund white seabass (Chen et al. 2000) and was propagated in the Chinook salmon embryo (CHSE)-214 cell line (Lannan et al. 1984 ) at $20^{\circ} \mathrm{C}$ as previously described (Chen et al. 2000). Bacterial concentrations were estimated by $50 \%$ tissue culture infective dose $\left(\mathrm{TCID}_{50}\right)$ assays on CHSE214 cells as described by Fryer et al. (1992), except that the cells were incubated at $20^{\circ} \mathrm{C}$ for $21 \mathrm{~d}$. End-point dilution assays were used to calculate the concentrations of WSB-98 in culture supernatant or fish tissues (Reed \& Muench 1938).

Experimental exposure and sample collection. A total of 150 white seabass were exposed to $1.26 \times 10^{2} \mathrm{TCID}_{50}$ Piscirickettsia salmonis fish ${ }^{-1}$ (exposed) via intraperitoneal injection and held in one 2151 tank, while 50 additional fish were injected with cell culture media alone (control) and held in a separate $215 \mathrm{l}$ tank. To minimize handling stress during the injections, fish were anesthetized first by bath administration of methane tricaine sulfonate (MS-222) at a concentration of $100 \mathrm{mg} \mathrm{l}^{-1}$. The fish were observed at least twice daily during the course of the experiment. Dead or severely moribund fish were removed from the tanks and impression smears prepared to detect presence of the bacterium. Moribund or live fish sampled throughout the experiment were euthanized with an overdose of MS-222 at a concentration of $500 \mathrm{mg} \mathrm{l}^{-1}$ followed by cervical dislocation. After the period of acute mortality, fish were lethally sampled at selected intervals from both the exposed and control groups. On 28, 43, 48, 56, 69, 76, 109 and $123 \mathrm{~d}$ post injection (dpi), fish were sampled to assess detection of $P$. salmonis using PCR and, in some cases, tissue culture methods. For detection of serum antibodies to P. salmonis, blood was collected from exposed and control fish on Days 48 ( $\mathrm{n}=10$ exposed, $\mathrm{n}=5$ control) and 56 ( $\mathrm{n}=9$ exposed, $\mathrm{n}=5$ control) post exposure, and only from exposed fish on Day $76(n=10)$. At 123 dpi, the remaining survivors were sampled from both exposed $(\mathrm{n}=30)$ and control $(n=15)$ groups for ELISA, and 10 from each 
of these groups were also processed for histological examination. Blood was collected from the caudal vessels into vacutainer tubes and the serum recovered following centrifugation. These samples were stored at $-20^{\circ} \mathrm{C}$ prior to analysis by ELISA for the presence of anti-P. salmonis antibodies. Tissues for histological evaluation, comprising portions of the gill, heart, kidney, liver, spleen and posterior intestine, were placed in Davidson's solution (Humason 1979) for approximately $16 \mathrm{~h}$, and then transferred to $70 \%$ ethanol. Tissues were then processed for routine paraffin embedding, sectioning, and staining with hematoxylin and eosin (H\&E). Impression smears made directly from liver tissues were air-dried for $1 \mathrm{~h}$, fixed in $100 \%$ methanol for $5 \mathrm{~min}$, and then stained with May-Grünwald Giemsa.

Reisolation of WSB-98. Reisolation and determination of the concentrations of WSB-98 in the kidney and liver of injected white seabass were used to evaluate infection intensity during the peak of mortality post injection. Tissues from freshly dead fish were removed aseptically and homogenized in minimal essential medium (MEM) without sodium bicarbonate supplemented with $2 \%$ fetal bovine serum, 20 mM L-glutamine and buffered with 25 mM HEPES (MEM-2 + HEPES). The homogenate was centrifuged at $208 \times g$ at $4^{\circ} \mathrm{C}$ for $1 \mathrm{~min}$ and the resulting supernatant was serially diluted in MEM-2 + HEPES. Concentrations of the bacterium in fish tissues were estimated by TCID $_{50}$ assays on CHSE-214 cells.

Detection of Piscirickettsia salmonis-specific DNA. Liver tissues were collected at each sampling point and stored dry at $-80^{\circ} \mathrm{C}$ until processed. DNA was extracted and purified from each sample using the Qiagen DNeasy ${ }^{\mathrm{TM}}$ kit, rodent tail protocol. PCR reactions were conducted on $300 \mathrm{ng}$ total DNA per sample, and each sample was tested 3 times (in 3 separate reactions) using a PTC-100 thermal cycler (MJ Research). P. salmonis rDNA was amplified using the primers described by Mauel et al. (1996). Conditions for the PCR test were similar to those previously described (Mauel et al. 1996) with a few exceptions. The eubacterial primer concentrations in the first round were $0.5 \mu \mathrm{M}, 0.8 \mathrm{U}$ of Taq polymerase was used per reaction and the first round of reactions were performed in 25 cycles. The cycling profile for the first round was $94^{\circ} \mathrm{C}$ for $30 \mathrm{~s}, 55^{\circ} \mathrm{C}$ for $1 \mathrm{~min}$ and $72^{\circ} \mathrm{C}$ for $1.5 \mathrm{~min}$. The cycling profile for the second round was $94^{\circ} \mathrm{C}$ for $30 \mathrm{~s}, 60^{\circ} \mathrm{C}$ for $45 \mathrm{~s}$ and $72^{\circ} \mathrm{C}$ for $30 \mathrm{~s}$. After amplification, products were evaluated by agarose gel $(1.5 \%)$ electrophoresis and ethidium bromide staining.

Detection of Piscirickettsia salmonis by immunohistocytochemistry. Paraffin-embedded tissues from 2 fish each from the exposed and control groups surviving to 4 mo post injection were further processed for immunohistochemical staining. Briefly, sections were deparaf- finized with 2 changes of xylene for 5 min each, then hydrated through a graded ethanol series $(100,95,70 \%)$, followed by distilled water and finally phosphatebuffered saline (PBS), all steps of 3 min each. Slides were blocked with $10 \%$ goat serum in PBS for 30 min at $25^{\circ} \mathrm{C}$, a temperature used for all subsequent steps in the immunostaining process. The goat serum was removed and $250 \mu \mathrm{l}$ of rabbit anti-P. salmonis antibody at a dilution of 1:1000 in PBS was added to the slides and allowed to incubate for $60 \mathrm{~min}$. Next, $250 \mu \mathrm{l}$ of biotinylated goat antirabbit antibody at a dilution of 1:250 in PBS was added and incubated for $60 \mathrm{~min}$. Lastly, peroxidase-streptavidin diluted 1:250 in PBS was added to each slide and incubated for $15 \mathrm{~min}$. After the primary and secondary antibody incubations and as a final step, slides were rinsed 3 times with PBS. Prior to staining, the slides were rinsed once with distilled water. Aminoethyl carbazole (AEC) was added for 3 min using the Zymed AEC substrate kit according to manufacturer's instructions. Following 3 washes with distilled water, the slides were counterstained with Mayer's hematoxylin solution, $0.1 \%$ (w/v) for 3 min followed by 3 washes with distilled water. Aqueous dry mounting medium was added to the wet slides and allowed to dry overnight. Lastly, a glass coverslip was applied using mounting medium.

Enzyme-linked immunosorbent assay (ELISA). An ELISA to detect the presence of serum anti-Piscirickettsia salmonis antibodies was developed and optimized similar to the procedures described by Case et al. (1983). To optimize each step of the procedures a positive serum sample, collected from a white seabass in an earlier study, was used. The serum was obtained from a fish which had survived a bath exposure to $P$. salmonis Isolate WSB-98 that resulted in a $40 \%$ cumulative mortality in the population (Arkush et al. 2005). At $70 \mathrm{~d}$ post initial exposure to $P$. salmonis the fish was re-exposed by intraperitoneal injection to $P$. salmonis $(0.1 \mathrm{ml}$ containing $10^{2.5} \mathrm{TCID}_{50} \mathrm{ml}^{-1}$ ) and then bled $28 \mathrm{~d}$ later. The serum negative control was derived from a control fish from the same group of white seabass used for the $P$. salmonis exposures for the positive serum sample but was never exposed to the bacterium. The antigen used for the ELISA was prepared similarly to that described by Kuzyk et al. (1996). Replicate $185 \mathrm{~cm}^{2}$ flasks with monolayers of CHSE-214 cells were inoculated with $P$. salmonis and incubated at $20^{\circ} \mathrm{C}$ until cytopathic effects were complete. The cells and supernatant from all flasks ( $\mathrm{n}=15$ ) were combined in 1 flask, mixed well; then an aliquot was removed for titration. The mixture was then centrifuged at $10000 \times g$ at $4^{\circ} \mathrm{C}$ for $30 \mathrm{~min}$. The resulting pellet was resuspended in $5 \mathrm{ml}$ of MEM with no serum or antibiotics (MEM-0). The suspension was then passed through a $21 \mathrm{~g}$ needle approximately 5 times and further homogenized by 10 strokes in a Tenbrock grinder (Fisher Scientific). The suspension 
was then centrifuged at $200 \times g$ for $10 \mathrm{~min}$ at $4^{\circ} \mathrm{C}$. The supernatant was retained and passed through an AP-20 filter (Millipore) pre-moistened with MEM-0. The filtrate was then centrifuged at $17600 \times g$ for $15 \mathrm{~min}$ at $4^{\circ} \mathrm{C}$ and the pellet resuspended in 1.5 to $2 \mathrm{ml}$ PBS. Preparations were then separated into smaller volumes and frozen at $-80^{\circ} \mathrm{C}$.

Concentrations of each of the following reagents for the ELISA were optimized: coating antigen consisting of purified Piscirickettsia salmonis, a biotinylated polyclonal rabbit anti-white seabass Ig (anti-WSB Ig) and the horseradish peroxidase (HRP)-streptavidin (SA) conjugate (Kirkegaard \& Perry Laboratories). Optimal conditions were identified by titrating each reagent and determining the concentration that generated the maximum positive to negative (P:N) ratio.

The ELISA plates (Falcon) were coated with $50 \mu \mathrm{l}$ well ${ }^{-1}$ of purified bacteria $\left(4 \mu \mathrm{g} \mathrm{ml}^{-1}\right)$ in PBS for $12 \mathrm{~h}$ at $4^{\circ} \mathrm{C}$. After blocking the wells with $2 \%$ non-fat dried milk in PBS, $50 \mu \mathrm{l}$ well $^{-1}$ of CHSE-adsorbed white seabass serum diluted 1:400 were added and incubated for $2 \mathrm{~h}$. The plates were washed 5 times with PBS containing $0.1 \%$ Tween-20 and incubated for $1 \mathrm{~h}$ at $21^{\circ} \mathrm{C}$ with $50 \mu \mathrm{l} \mathrm{well}^{-1}$ of biotinylated anti-WSB Ig diluted 1:800. Following 5 washes, plates were incubated for $30 \mathrm{~min}$ at $21^{\circ} \mathrm{C}$ with $50 \mu \mathrm{l}$ of HRP-SA diluted 1:800. The plates were washed 9 times and the color reaction was initiated by addition of $100 \mu \mathrm{l}$ well $^{-1}$ of 3,3',5,5'-tetramethyl benzidine (TMB) $\left(50 \mu \mathrm{g} \mathrm{ml}^{-1} \mathrm{TMB}\right.$ in $50 \mathrm{mM}$ citric acid buffer, $\mathrm{pH} 4.8$, and $0.01 \% \mathrm{H}_{2} \mathrm{O}_{2}$ ). After $15 \mathrm{~min}$ at $21^{\circ} \mathrm{C}$, color development was arrested by adding $50 \mu \mathrm{l}$ well ${ }^{-1}$ of $1 \mathrm{M} \mathrm{H}_{2} \mathrm{SO}_{4}$ and the optical densities (OD) determined with a Bio-Tek Ceres 900HDi ELISA reader (Bio-Tek Instruments) at a wavelength of $450 \mathrm{~nm}$. All dilutions of white seabass serum, biotinylated rabbit anti-WSB Ig and HRP-SA were made in PBS with $0.05 \%$ Tween-20 and $1 \%$ non-fat dried milk. All washes were with PBS containing 0.1\% Tween-20. Each plate used in all assays contained both a positive and negative serum control from which OD values for each test sample could be expressed as a \% of the positive control. If a test sample had a higher background against CHSE-214 cells alone and an OD value comparable to that of the negative control, the calculated value (a negative number) was reported as zero. The frequency or number of fish in the group at each \% of the positive control serum (reactivity) was plotted.

\section{RESULTS}

\section{Mortality}

Mortality among white seabass exposed to Piscirickettsia salmonis began $11 \mathrm{dpi}$ and subsided by $27 \mathrm{dpi}$, by which time 43 fish had died (29\%). P. salmonis was detected in Giemsa-stained impression smears of the liver from all 43 dead fish (data not shown), and the bacterium was reisolated in cell culture from fish tested throughout the period of acute mortality $(n=6$, range of $1.58 \times 10^{4}$ to $2.81 \times 10^{5} \mathrm{TCID}_{50} \mathrm{~g}^{-1}$ fish tissue).

\section{PCR detection}

The PCR assay detected Piscirickettsia salmonis-specific DNA in 5 of 10 fish sampled on 28 dpi (Table 1) and bacteria were recovered in cell culture from one of these fish $\left(7.4 \times 10^{1}\right.$ TCID $\left._{50} \mathrm{~g}^{-1}\right)$. By $43 \mathrm{dpi}, 2$ of $10 \mathrm{fish}$ were PCR positive but none were culture positive. At 48 and 56 dpi, 4 of 10 and 3 of 10 fish were PCR positive, respectively, and no fish from either time point was culture positive and therefore no cell culture reisolation was attempted for the remaining time points. The prevalence of fish with $P$. salmonis-specific DNA in the population remained similar on subsequent sampled dates, with 4 of 10 positive at 69 dpi, 3 of 10 positive at $76 \mathrm{dpi}$, and 4 of 10 positive at $109 \mathrm{dpi}$. At the end of the experiment (123 dpi), 4 of 30 fish were PCR positive. Throughout the experiment, $P$. salmonis was never detected by PCR in the unexposed control group. Giemsa-stained impression smears of the liver were prepared from all fish sampled (data not shown). Using this method, $P$. salmonis was detected in only 1 sampled fish that was both PCR and culture positive (28 dpi). We were unable to detect the bacterium in stained smears from all subsequently sampled fish, including those that were PCR positive. On 46 and 59 dpi, 2 fish died in the exposed group and P. salmonis was detected in 1 of these fish by PCR. In the unexposed control group, 2 fish died on 97 and 109 dpi, but P. salmonis was not detected by PCR.

\section{ELISA detection of anti-Piscirickettsia salmonis antibodies}

For the ELISA, the optimal serum concentration that provided the highest P:N ratio was 1:400. We used this serum dilution of our positive and negative serum controls for all subsequent reagent titrations and $\mathrm{P}: \mathrm{N}$ ratio determinations. From these titrations the following optimal concentrations of each reagent for the ELISA was determined: purified $P$. salmonis coating antigen, $4 \mu \mathrm{g} \mathrm{ml}^{-1}$; biotinylated rabbit anti-WSB Ig, diluted to 1:800 for a final concentration of $8.75 \mu \mathrm{g} \mathrm{ml} \mathrm{m}^{-1}$; and HRP-SA, diluted to 1:800 for a final concentration of $0.5 \mathrm{mg} \mathrm{ml}^{-1}$. All subsequent ELISAs utilized these reagent concentrations with times for each step as indicated previously. 
White seabass sampled from the control exposure group had little anti-Piscirickettsia salmonis antibody in their serum (Table 1, Fig. 1). For 23 of 25 control fish tested, the OD values were below $5 \%$ of that for the positive control serum, with the remaining 2 fish having values below $10 \%$ of the positive control serum. Of the 59 fish tested from the exposed group, 48 fish had OD readings $>10 \%$ of the positive control serum (Table 1, Fig. 2).

\section{Microscopic lesions and immunohistochemical staining}

Microscopic lesions were prominent in the liver and kidney of 9 of 10 fish from the Piscirickettsia salmonisexposed group examined at $123 \mathrm{dpi}$. There were no remarkable lesions in the spleen, posterior intestine, heart or gill of any of the P. salmonis-injected white seabass. There were no lesions found in any of the 10 control white seabass not exposed to P. salmonis. Liver and kidney lesions consisted of single to multiple and coalescing granulomas in various stages of formation (Fig. 3A). Younger granulomas were characterized by the presence of smaller aggregates of macrophages $(<50 \mu \mathrm{m}$ in diameter) without an epithelioid layer (Fig. 3B). Well-developed granulomas were the most common lesion found and these contained a central area of necrosis and thick layers of epithelioid macrophages. Additional lesions that were less prominent among $P$. salmonis-exposed fish were hepatocellular glycogen depletion, single cell necrosis, spongiosis hepatitis and hepatocellular regeneration (not shown). Bacterial cells were not easily observed in most granulomas but, when

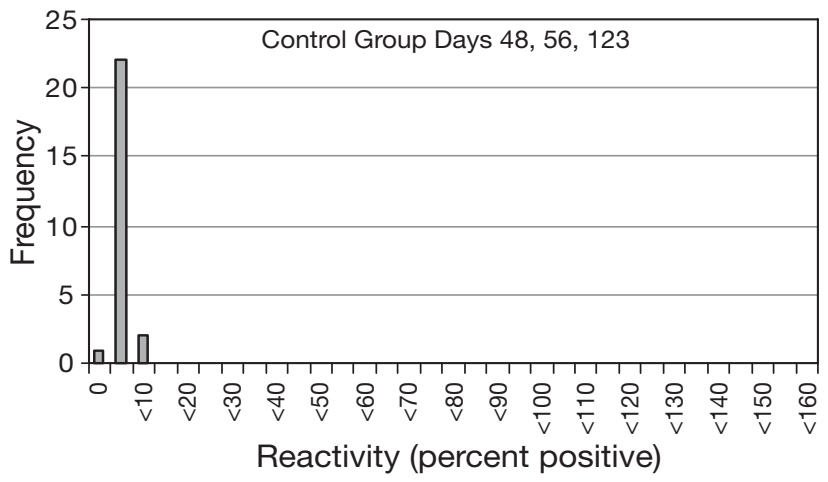

Fig. 1. Atractoscion nobilis. Enzyme-linked immunosorbent assay (ELISA) detection of anti-Piscirickettsia salmonis antibodies in serum of fish exposed to tissue culture media alone, as control, sampled at 48, 56 and $123 \mathrm{~d}$ post injection. Frequency or number of fish at relevant ELISA value for each serum sample expressed as percent of the positive control included in each assay

seen, were near the periphery of the lesions (Fig. 3C). Bacterial cells were observed within granulomatous lesions in histological sections from exposed fish sampled at 123 dpi by immunohistochemical staining using rabbit polyclonal antisera raised against $P$. salmonis, but none were seen in tissue sections from control fish at the same sampling time point (data not shown).

\section{DISCUSSION}

Detection of Piscirickettsia salmonis-specific DNA by PCR suggests that white seabass surviving initial experimental exposures may harbor the bacterium in a

Table 1. Atractoscion nobilis. Detection of Piscirickettsia salmonis (white seabass Isolate 98, WSB-98) in live juvenile white seabass sampled following experimental exposure to bacterium by intraperitoneal injection. Exposed $=1.26 \times 10^{2}$ tissue culture infective dose $\left(\mathrm{TCID}_{50}\right)$; Control = minimal essential media alone. Detection methods comprised polymerase chain reaction $(\mathrm{PCR})$, amplification of DNA from liver tissues; enzyme-linked immunosorbent assay, ELISA, for serum antibodies (\% of positive control); and cell culture reisolation on CHSE-214 cells. dpi $=$ days post injection; $\mathrm{n}=\mathrm{no}$. of fish; $\mathrm{n} / \mathrm{n}=\mathrm{no}$. positive/no. sampled; nd $=$ not done

\begin{tabular}{|c|c|c|c|c|c|}
\hline Group/dpi & $\mathrm{n}$ & $\begin{array}{l}\text { Mean wt } \\
(\mathrm{g})\end{array}$ & $\begin{array}{l}\text { PCR } \\
(\mathrm{n} / \mathrm{n})\end{array}$ & $\begin{array}{c}\text { ELISA } \\
\text { Range (median) }\end{array}$ & $\begin{array}{l}\text { Cell culture } \\
(\mathrm{n} / \mathrm{n})\end{array}$ \\
\hline Exposed/28 & 10 & 50.7 & $5 / 10$ & nd & $1 / 10$ \\
\hline Exposed/43 & 10 & 71.4 & $2 / 10$ & nd & $0 / 10$ \\
\hline Control/43 & 5 & 65.0 & $0 / 5$ & nd & nd \\
\hline Exposed/48 & 10 & 54.8 & $4 / 10$ & $9.1-136.6(67.9)$ & $0 / 10$ \\
\hline Control/48 & 5 & 85.8 & $0 / 5$ & $0-3.4(2.5)$ & nd \\
\hline Exposed/56 & 10 & 75.4 & $3 / 10$ & $0-157.8(26.1)$ & $0 / 10$ \\
\hline Control/56 & 5 & 88.2 & $0 / 5$ & $1.6-2.7(1.9)$ & nd \\
\hline Exposed/69 & 10 & 85.6 & $4 / 10$ & nd & nd \\
\hline Control/69 & 5 & 108.6 & $0 / 5$ & nd & nd \\
\hline Exposed/76 & 10 & 78.6 & $3 / 10$ & $6.0-50.5(11.9)$ & nd \\
\hline Exposed/109 & 10 & 100.1 & $4 / 10$ & nd & nd \\
\hline Exposed/123 & 30 & 110.4 & $4 / 30$ & $1.7-131.3(32.8)$ & nd \\
\hline Control/123 & 26 & 115.6 & $0 / 26$ & $1.1-9.1(2.5)$ & nd \\
\hline
\end{tabular}



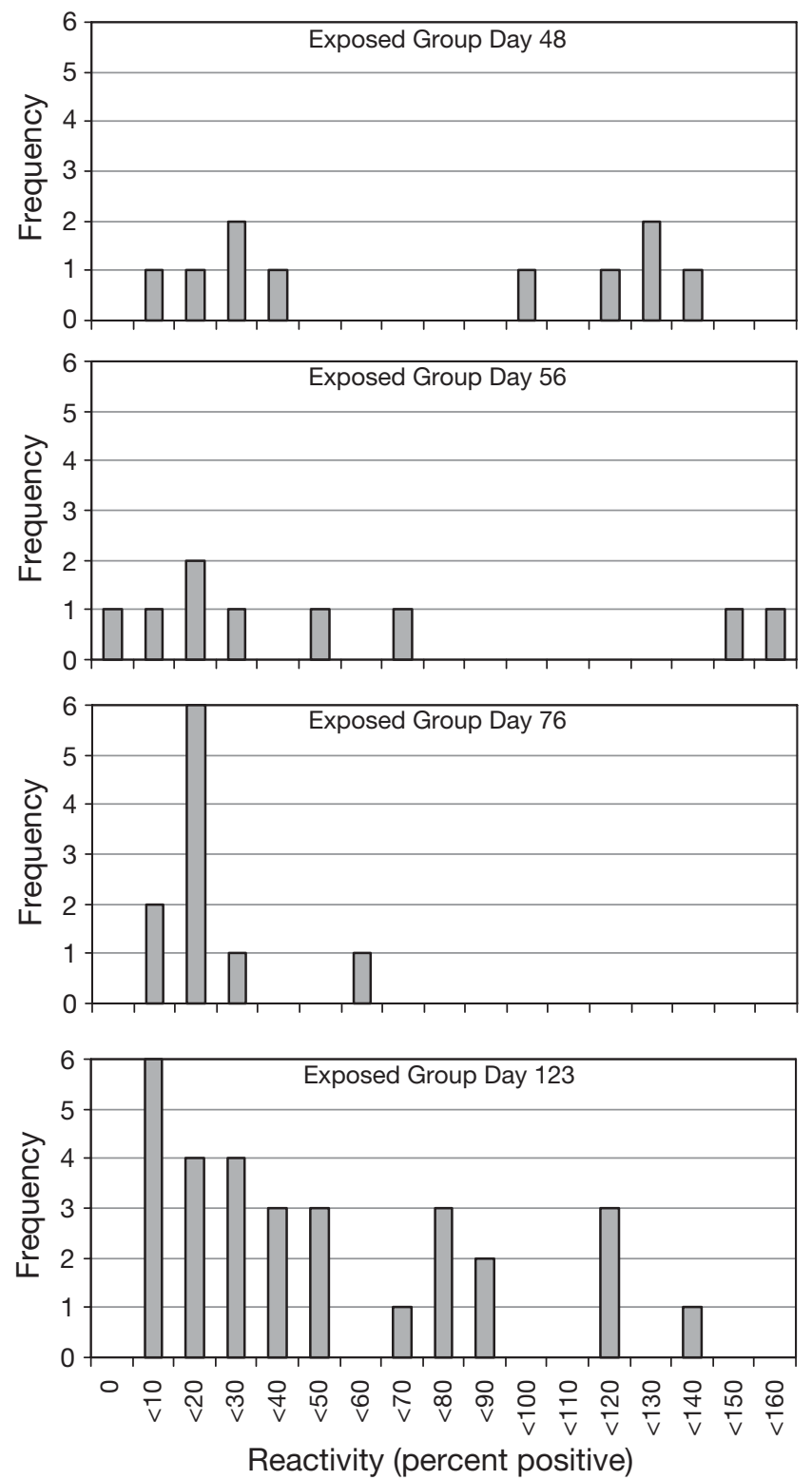

Fig. 2. Atractoscion nobilis. Enzyme-linked immunosorbent assay (ELISA) detection of anti-Piscirickettsia salmonis antibodies in serum of fish that survived experimental exposure to $P$. salmonis, sampled at $48,56,76$, and $123 \mathrm{~d}$ post injection. Frequency or number of fish at relevant ELISA value for each serum sample expressed as percent of the positive control included in each assay

persistent state for periods up to at least $123 \mathrm{~d}$ and presumably beyond. In addition to detection of bacterial DNA by PCR, suspected carriers of $P$. salmonis had microscopic pathological lesions characteristic of chronic forms of $P$. salmonis, as observed in salmonid fish, and bacterial antigens were detected in these lesions by immunohistochemical stains. Detection of serum anti- $P$. salmonis antibodies in most experimentally exposed fish (48 of 59 or $81.4 \%$ ) indicates that serologic tests may be good indicators of prior exposure and perhaps also of a continuing persistence of the bacterium in wild and or cultured white seabass populations.

The white seabass in the current experimental exposures to Piscirickettsia salmonis received doses equivalent to those in a prior study by Arkush et al. (2005) and mortality rates and levels of bacteria recovered from dead fish were similar in both studies. During the period of acute mortality in the current study, the bacterium was detected in Giemsa-stained impression smears of liver tissues collected from all dead fish and bacteria were isolated in cell culture from all fish examined by this procedure. In contrast, during sampling of live fish from 28 to $123 \mathrm{dpi}$, the bacterium was not detected in impression smears or by cell culture in any of the fish sampled except for 1 exposed fish collected at $28 \mathrm{dpi}$. However, PCR detection of $P$. salmonis DNA indicated that the bacterium was present throughout the 4 mo sampling period. Also, microscopic pathology associated with the bacterium was seen in nearly all exposed fish (9 of 10) examined at the end of the experiment, and immunohistochemical staining using rabbit anti-P. salmonis polyclonal antisera confirmed the presence of $P$. salmonis antigens associated with these lesions. Large numbers of bacteria were not evident in these lesions and this may in part explain the difficulty encountered in cell culture isolation attempts. Similar difficulties with isolation of bacteria in the chronic phases of other diseases have been reported (Evelyn et al. 1981, Cipriano et al. 1996, Bullock et al. 1997, Hiney et al. 1997). Survival and thus persistence of $P$. salmonis in an intracellular location provides distinct advantages including evasion of host immunological surveillance and antibiotic therapy, particularly when sequestered within granulomatous lesions. Intracellular survival is a key step in persistence of the bacterium and the maintenance of a carrier state (Young \& Chapman 1978, Bruno 1986, Gutenberger et al. 1997, Mauel \& Miller 2002), even following antibiotic treatments (Fryer \& Hedrick 2003). Although not a focus of the current study, reactivation of piscirickettsiosis in surviving fish is needed to fully demonstrate the carrier state in white seabass that have survived initial exposure to $P$. salmonis. Such studies have been conducted with asymptomatic carriers of Aeromonas salmonicida, where reactivation of infections follows immunosuppressive stressors such as the stress-induced furunculosis test (Bullock et al. 1997) or moderate stress following vaccination against the bacterium itself. In an experimental study with Atlantic salmon Salmo salar parr subclinically infected with A. salmonicida, most of the 98 vaccinated fish (96 of 97) died from furunculosis soon after being sub- 


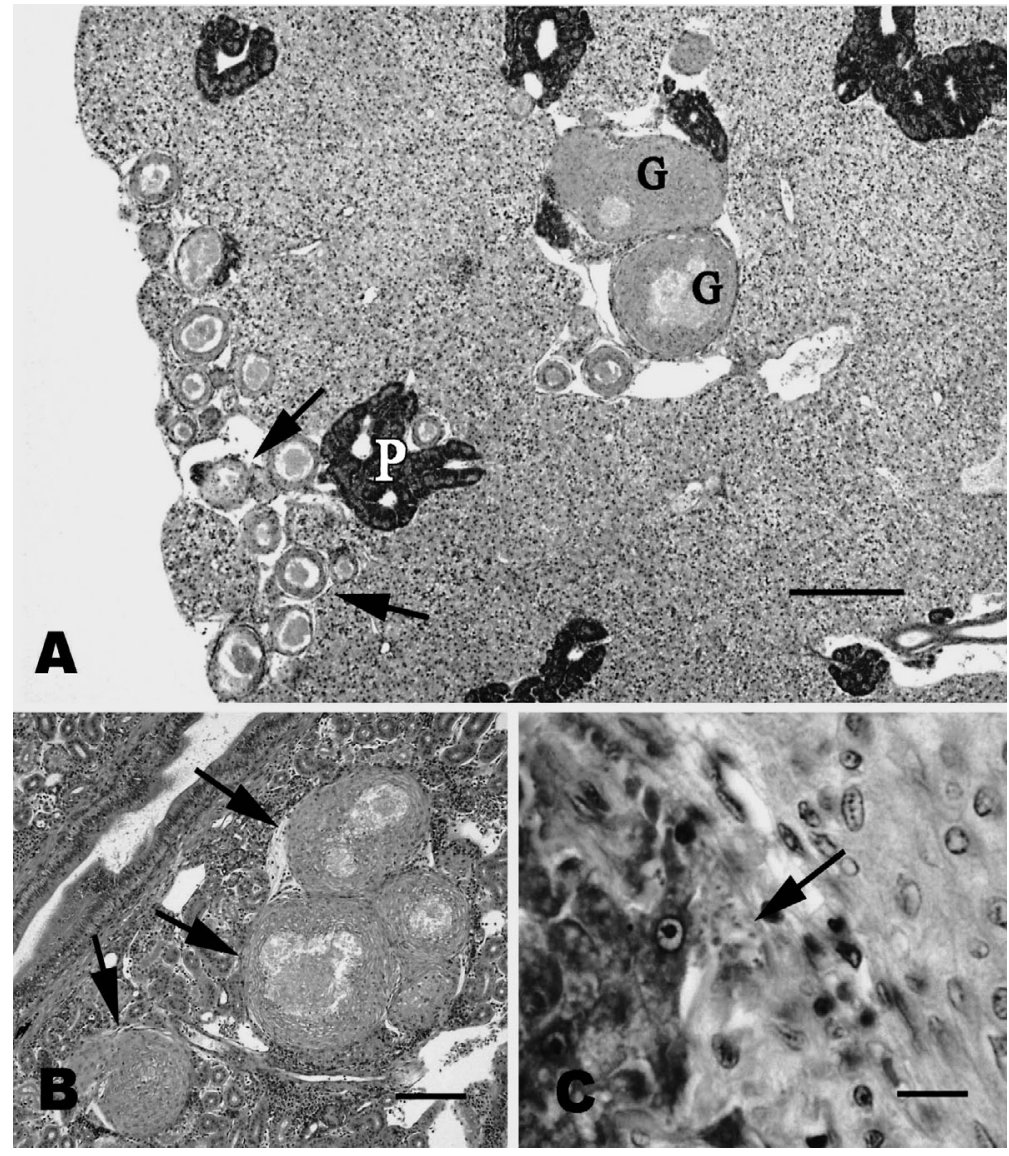

Fig. 3. Atractoscion nobilis. Microscopic lesions present in liver and kidney of white seabass surviving $123 \mathrm{~d}$ after intraperitoneal injection with Piscirickettsia salmonis. (A) Large and well-developed granulomas (G) and smaller and numerous granulomas (arrowed) near islet of exocrine pancreas (P) in liver; (B) large granulomas (arrowed) with caseous centers in posterior kidney; (C) putative intracellular $P$. salmonis (arrowed) at exterior of a granuloma in liver. Scale bars = (A) $200 \mu \mathrm{m}$, (B) $100 \mu \mathrm{m}$, (C) $10 \mu \mathrm{m}$

tion. However, in following antibody levels in fish that had been vaccinated against the nodavirus, they found high variations in individual responses to immunization, particularly following boosting at 4 and $6 \mathrm{wk}$. Individual fish-to-fish antibody variation has been documented for other bacterial and viral pathogens, including Vibrio anguillarum (Thorburn \& Jansson 1988), infectious pancreatic necrosis virus (Dixon 1996), and Renibacterium salmoninarum (Jansson \& Ljungberg 1998).

Overall, the presence of serum antiPiscirickettsia salmonis antibodies was the best indication of prior experimental exposures, as other detection methods including isolation in cell culture or direct observation of the bacterium in stained tissue impressions were less informative. As a result, culture efforts were discontinued after 56 dpi since recovery of $P$. salmonis from the 4 prior sampling times was largely unsuccessful. Several exposed white seabass harbored $P$. salmonis DNA as detected by PCR, but there was no apparent correlation between PCR-positive fish and the concentration of serum anti-P. salmonis antibodies. This lack of correlation may result from the dramatic difference observed between fish in the response to bacterial antigens whether administered by vaccination or active infection (Jansson \& Ljungberg 1998). The presence of serum anti-P. salmonis antibodies does not confirm the presence of live $P$. salmonis cells and thus an active carrier state in white seabass. However, ELISA detection of anti-

jected to moderate transport and temperature stress, while deaths of only 2 of the 17 dead fish in the amoxicillin-treated group were $A$. salmonicida-linked (Inglis et al. 1996).

Serum anti-Piscirickettsia salmonis antibodies were detected in white seabass as early as $48 \mathrm{dpi}$ and were present among $P$. salmonis-exposed fish throughout the sampling period. Median antibody levels were highest at $48 \mathrm{dpi}(67.9 \%$ of positive control) and decreased to approximately half that value by $123 \mathrm{dpi}$ (32.8\% of positive control), but there was a wide range in the ELISA values, both within and between sample time points. Interestingly, in repeated serological examination of captive sea bass Dicentrarchus labrax for the presence of serum antibodies to nodavirus, Breuil \& Romestand (1999) showed that there were no dramatic changes in the proportions of seropositive and seronegative fish over a 5 mo period of cohabita-
$P$. salmonis antibodies in the present study was shown to be a reliable indicator of prior exposure to the bacterium, particularly when viewed at the population level. These initial laboratory results suggest that presently the most accurate assessments of the $P$. salmonis infection status in populations of white seabass are best obtained by combinations of serologic screening and specific PCR testing.

Histological examination of exposed fish sampled at 4 mo post exposure revealed single to multiple granulomatous lesions in the liver and kidney similar to those described in earlier reports of Piscirickettsia salmonis infection in white seabass (Arkush et al. 2005). We suspect that these lesions contain viable bacteria that may contribute to the transmission of the agent, but this was not determined in the current study. Immunohistochemical staining of tissues from exposed fish did identify $P$. salmonis-specific antigens 
within lesions, although viability would have to be assessed by other methods (e.g. culture or transmission studies).

Horizontal transmission of Piscirickettsia salmonis has been demonstrated in experimental studies using salmonid fish in both fresh- and seawater (Cvitanich et al. 1991, Almendras et al. 1997). The skin and gills are portals of entry for P. salmonis (Smith et al. 1999) and oral intubation with the bacterium has been shown to lead to infection (Almendras et al. 1997). That white seabass receiving intraperitoneal injections with $P$. salmonis can transmit the bacterium to both Chinook and coho salmon in seawater at $16^{\circ} \mathrm{C}$ has been demonstrated by Arkush et al. (2005). In that study, white seabass with clinical signs were cohabited with the salmonid fish. Vertical transmission of $P$. salmonis also has been demonstrated in both naturally infected and experimentally exposed salmonid fish, representing another mode by which asymptomatic carrier fish could be created (Larenas et al. 1996, 1999, 2003).

In the current study, experimental infections in white seabass were induced by injection of the bacterium, which differs from natural infections by circumventing the skin and mucus barriers of the fish. However, the systemic infection established by these experimental exposures both in white seabass and salmonid fish are identical to those observed in naturally acquired disease, suggesting that similar steps in the pathogenesis are shared in both types of infection (Fryer \& Hedrick 2003, Arkush et al. 2005). In the current study, intraperitoneal injections were chosen as the preferred exposure route to ensure that all fish received a uniform dose. White seabass that survived these exposures appeared outwardly healthy. However, direct (PCR) methods demonstrated that exposed fish can harbor Piscirickettsia salmonis for periods up to 4 mo and presumably beyond. Additional studies that combine these detection methods with transmission trials to naïve white seabass and, potentially, other fish species are needed. Also, examinations of the potential carrier state among wild and captive white seabass populations that have survived naturally acquired infections (e.g. waterborne immersion) should be conducted.

Acknowledgements. We thank the personnel from HubbsSeaWorld Research Institute and the Ocean Resources Enhancement and Hatchery Program for providing white seabass for this study. We also thank Terry McDowell and Kevin Kwak for their technical assistance. This paper was supported in part by the California Department of Fish and Game (Contract No. 01-01255V). This is Contribution No. 2358, Bodega Marine Laboratory, University of California at Davis.

\section{LITERATURE CITED}

Almendras FE, Fuentealba IC, Jones SRM, Markham F, Spangler E (1997) Experimental infection and horizontal transmission of Piscirickettsia salmonis in freshwaterraised Atlantic salmon, Salmo salar L. J Fish Dis 20: $409-418$

Arkush KD, McBride AM, Mendonca HL, Okihiro MS, Andree KB, Marshall S, Henriquez V, Hedrick RP (2005) Genetic characterization and experimental pathogenesis of Piscirickettsia salmonis isolated from white seabass Atractoscion nobilis. Dis Aquat Org 63:139-149

Bravo S, Campos M (1989) Coho salmon syndrome in Chile. Newsl Am Fish Soc Fish Health 17:3

Breuil G, Romestand B (1999) A rapid ELISA method for detecting specific antibody level against nodavirus in the serum of the sea bass, Dicentrarchus labrax (L.): application to the screening of spawners in a sea bass hatchery. J Fish Dis 22:45-52

Brocklebank JR, Speare DJ, Armstrong RD, Evelyn T (1992) Septicemia suspected to be caused by a rickettsia-like agent in farmed Atlantic salmon. Can Vet J 33:407-408

Bruno DW (1986) Histopathology of bacterial kidney disease in laboratory infected rainbow trout, Salmo gairdneri Richardson, and Atlantic salmon, Salmo salar L., with reference to naturally infected fish. J Fish Dis 9:523-537

Bullock GL, Cipriano RC, Schill WB (1997) Culture and serodiagnostic detection of Aeromonas salmonicida from covertly-infected rainbow trout given the stress-induced furunculosis test. Biomed Lett 55:169-177

Case JT, Ardans AA, Bolton DC, Reynolds BJ (1983) Optimization of parameters for detecting antibodies against infectious bronchitis virus using an enzyme linked immunosorbent assay: temporal response to vaccination and challenge with live virus. Avian Dis 27:196-210

Chen MF, Yun S, Marty GD, McDowell TS and 5 others (2000) A Piscirickettsia salmonis-like bacterium associated with mortality of white seabass Atractoscion nobilis. Dis Aquat Org 43:117-126

Cipriano RC, Bullock GL, Schill WB, Kretschmann R (1996) Enhanced culture of Aeromonas salmonicida from covertly infected rainbow trout following administration of the stress induced furunculosis test. Biomed Lett 54: $105-112$

Comps M, Raymond MJ, Plassiart GN (1996) Rickettsia-like organism infecting juvenile sea-bass Dicentrarchus labrax. Bull Eur Assoc Fish Pathol 16:30-33

Cusack RR, Groman DB, Jones SRM (2002) Rickettsial infection in farmed Atlantic salmon in eastern Canada. Can Vet J 43:435-440

Cvitanich JD, Garate NO, Smith CE (1991) The isolation of a rickettsia-like organism causing disease and mortality in Chilean salmonids and its confirmation by Koch's postulate. J Fish Dis 14:121-145

Dixon PF (1996) Use of antibody screening for the identification of rainbow trout carriers of infectious pancreatic necrosis virus in a broodstock management scheme: preliminary study. Bull Eur Assoc Fish Pathol 16:125-128

Evelyn TPT (1992) Salmonid rickettsial septicemia. Can Spec Publ Fish Aquat Sci 116:18-19

Evelyn TPT, Ketcheson JE, Prosperi-Porta L (1981) The clinical significance of immunofluorescence-based diagnoses of the bacterial kidney disease carrier. Fish Pathol 15: 293-300

Fryer JL, Hedrick RP (2003) Piscirickettsia salmonis: a Gramnegative intracellular bacterial pathogen of fish. J Fish Dis $26: 251-262$ 
Fryer JL, Lannan CN, Giovannoni SJ, Wood ND (1992) Piscirickettsia salmonis gen. nov., sp. nov., the causative agent of an epizootic disease in salmonid fishes. Int J Syst Bacteriol 42:120-126

Grant AN, Brown AG, Cox DI, Birbeck TH, Griffen AA (1996) Rickettsia-like organism in farmed salmon. Vet Rec 138: 423

Gutenberger SK, Duimstra JR, Rohovec JS, Fryer JL (1997) Intracellular survival of Renibacterium salmoninarum in trout mononuclear phagocytes. Dis Aquat Org 28:93-106

Hiney M, Smith P, Bernoth E (1997) Covert Aeromonas salmonicida infections. In: Bernoth EM, Ellis AE, Midtlyng PJ, Oliver G, Smith PR (eds) Furunculosis: multidisciplinary fish disease research. Academic Press, London, p 54-97

Humason GL (1979) Animal tissue techniques. Freeman, San Francisco, CA

House ML, Hedrick RP, Winton JR, Fryer JL (in press) An isolate of Piscirickettsia salmonis from white seabass Atractoscion nobilis is fully virulent for coho salmon Oncorhynchus kisutch. J Aquat Anim Health

Inglis $\mathrm{V}$, Robertson $\mathrm{D}$, Miller $\mathrm{K}$, Thompson $\mathrm{KD}$, Richards $\mathrm{RH}$ (1996) Antibiotic protection against recrudescence of latent Aeromonas salmonicida during furunculosis vaccination. J Fish Dis 19:341-348

Jansson E, Ljungberg O (1998) Detection of humoral antibodies to Renibacterium salmoninarum in rainbow trout Oncorhynchus mykiss and Atlantic salmon Salmo salar challenged by immersion and in naturally infected populations. Dis Aquat Org 33:93-99

Kuzyk MA, Thornton JC, Kay WW (1996) Antigenic characterization of the salmonid pathogen Piscirickettsia salmonis. Infect Immun 64:5205-5210

Lannan CN, Fryer JL (1994) Extracellular survival of Piscirickettsia salmonis. J Fish Dis 17:545-548

Lannan CN, Winton JR, Fryer JL (1984) Fish cell lines: establishment and characterization of nine cell lines from salmonids. In Vitro 20:671-676

Larenas J, Astorga C, Contreras J, Smith P (1996) Deteccifin de Piscirickettsia salmonis en ovas fertilizadas provenientes de truchas arco iris (Oncorhynchus mykiss) experimentalmente infectadas. Arch Med Vet 28:161-166

Larenas J, Pérez B, Hidalgo L, Contreras J, Smith P (1999) Vertical transmission of Pisciricketttsia salmonis in coho salmon (Oncorhynchus kisutch) under farming conditions.

Editorial responsibility: David Bruno,

Aberdeen, UK
(Abstract), In: IXth International Conference Diseases of Fish and Shellfish (Abstracts). European Association of Fish Pathologists, Rhodes, p-069

Larenas JJ, Bartholomew J, Troncoso O, Fernández S and 5 others (2003) Experimental vertical transmission of Piscirickettsia salmonis and in vitro study of attachment and mode of entrance into the fish ovum. Dis Aquat Org 56: $25-30$

Mauel MJ, Miller DL (2002) Piscirickettsiosis and piscirickettsiosis-like infections in fish: a review. Vet Microbiol 87: 279-289

Mauel MJ, Giovannoni SJ, Fryer JL (1996) Development of polymerase chain reaction assays for detection, identification, and differentiation of Piscirickettsia salmonis. Dis Aquat Org 26:189-195

McCarthy Ú, Steiropoulos NA, Thompson KD, Adams A, Ellis AE, Ferguson HW (2005) Confirmation of Piscirickettsia salmonis as a pathogen in European sea bass Dicentrarchus labrax and phylogenetic comparison with salmonid strains. Dis Aquat Org 64:107-119

Olsen AB, Melby HP, Speilberg L, Evensen O, Hastein T (1997) Piscirickettsia salmonis infection in Atlantic salmon Salmo salar in Norway-epidemiological, pathological and microbiological findings. Dis Aquat Org 31:35-48

Reed LJ, Muench H (1938) A simple method of estimating fifty percent endpoints. Am J Hyg 27:493-497

Rodger HD, Drinan EM (1993) Observation of a rickettsia-like organism in Atlantic salmon, Salmo salar L., in Ireland. J Fish Dis 16:361-369

Skarmeta AM, Henriquez V, Zahr M, Orrego C, Marshall SH (2000) Isolation of a virulent Piscirickettsia salmonis from the brain of naturally infected coho salmon. Bull Eur Assoc Fish Pathol 20:261-264

Smith PA, Pizarro P, Ojeda P, Contreras J, Oyanedel S, Larenas J (1999) Routes of entry of Piscirickettsia salmonis in rainbow trout Oncorhynchus mykiss. Dis Aquat Org 37: 165-172

Thorburn M, Jansson E (1988) Frequency distributions in rainbow trout populations of absorbance values from an ELISA for Vibrio anguillarum antibodies. Dis Aquat Org 5: 171-177

Young CL, Chapman GB (1978) Ultrastructural aspects of the causative agent and histopathology of bacterial kidney disease in brook trout (Salvelinus fontinalis). J Fish Res Board Can 35:1234-1248

Submitted: December 9, 2005; Accepted: September 19, 2006 Proofs received from author(s): December 4, 2006 